Journal of Environmental Science and Sustainable Development

$12-31-2019$

\title{
RELATIONSHIP BETWEEN SUSTAINABLE OUTER SPACE LAW AND THE USE OF SATELLITE TECHNOLOGY IN HANDLING MARINE PLASTIC DEBRIS
}

\author{
Andreas Pramudianto \\ School of Environmental Science, Universitas Indonesia. Jl. Salemba Raya No.4 Jakarta Pusat 10430, \\ uipram@gmail.com
}

Follow this and additional works at: https://scholarhub.ui.ac.id/jessd

Part of the Environmental Law Commons, International Law Commons, and the Water Law Commons

\footnotetext{
Recommended Citation

Pramudianto, Andreas (2019). RELATIONSHIP BETWEEN SUSTAINABLE OUTER SPACE LAW AND THE USE OF SATELLITE TECHNOLOGY IN HANDLING MARINE PLASTIC DEBRIS. Journal of Environmental Science and Sustainable Development, 2(2), 228-241.

Available at: https://doi.org/10.7454/jessd.v2i2.1026

This Review Article is brought to you for free and open access by the School of Environmental Science at UI Scholars Hub. It has been accepted for inclusion in Journal of Environmental Science and Sustainable Development by an authorized editor of UI Scholars Hub.
} 


\title{
RELATIONSHIP BETWEEN SUSTAINABLE OUTER SPACE LAW AND THE USE OF SATELLITE TECHNOLOGY IN HANDLING MARINE PLASTIC DEBRIS
}

\author{
Andreas Pramudianto* \\ School of Environmental Science, Universitas Indonesia. Jl. Salemba Raya No.4 Jakarta \\ Pusat 10430
}

"Corresponding author: e-mail: uipram@gmail.com

(Received: 17 November 2019; Accepted: 25 December 2019; Published: 31 December 2019)

\begin{abstract}
Since the discovery of plastic material, which ends up as plastic waste after use and partly enters the sea, it has become a global problem that needs serious treatment. No international agreement exists about handling marine plastic debris. By contrast, national laws have been created to plastic bags and plastic debris. Currently, the existing legal instruments, especially in outer space law, are still traditional and inadequate. A sustainable new paradigm in outer space law is needed, such as the use of satellite technology, such as the COSMOS satellite by RKA Recosmos, for global environmental issues, including the ozone layer, climate change, biodiversity handling of hazardous and toxic waste, and rubbish, including marine plastic. Satellite technology is needed, especially in providing data and information and in observing the movement of plastic waste in the sea. International cooperation is needed to ensure complete and accurate data and information about the spread of marine plastic debris. This study aims to identify and analyze the role of sustainable outer space law in the handling of marine plastic debris using outer space technology such as satellites. The main research is study relations between law of the sea and outer space law. The methodology of this research uses normative legal research. The analysis of this research uses normative and juridical analysis methods. This research show that satellite technology is seldom to use in the study's marine debris moreover in the international law perspective. Preliminary results show that a sustainable outer space law requires all parties to cooperate and handle marine pollution.
\end{abstract}

Keywords: sustainable outer space law; international law; international environmental law; marine plastic debris; outer space technology; satellites

\section{Introduction}

Marine plastic debris is increasingly circulating widely in the sea. Approximately $60-80 \%$ of the world's litter is in form of plastic (Derraik, 2002). A mountain of marine debris called the Pacific Garbage Patch is floating in the Pacific Ocean (Harse, 2011). This location is high consentration of plastic debris were firstly observed in the North Pacific central Grey (Moore, Moore, Leecaster, \& Weisberg, 2001). Its location is thought to be around the North Pacific Sea at $135-155^{\circ}$ south latitude west and $35-42^{\circ}$ south latitude north. This problem worsens the marine environment and endangers living things and habitats. Marine plastic debris has 
even been ingested by marine animals (Vegter et al., 2014). Studies in 1999 averaged around 334,271 per $\mathrm{km}^{2}$ with a period of $5114 \mathrm{~g} / \mathrm{km}^{2}$. Plankton in the North Pacific Ocean region averaged 1,837,342 organisms per $\mathrm{km} 2$ with a mass of $841 \mathrm{~km}^{2}$, with a plastics-to-plankton ratio of 6:1 (Moore et al., 2001). In 2008, this ratio increased dramatically to 48:1 (Greenberg $\&$ Moore, 2011). This condition needs the spatial theory for the description of situation in the sea especially the use of satellite technology (Burkhoder, 2017)

Some international treaties have not yet clearly and firmly stipulated the provisions related to marine plastic debris. At present, only Annex V of the Marine Pollution Convention (MARPOL 1973/1978) regulates plastic debris. The United Nations Convention on the Law of the Sea (UNCLOS 1982) only emphasizes the importance of efforts to protect the marine environment but does not provide detailed rules regarding marine plastic debris. The 1989 Basel Convention on the Control of Transboundary Movements of Hazardous Wastes and Their Disposal, which regulates the movement of hazardous and toxic substances, at the 14th Conferences of the Parties has agreed to try to limit the movement of plastic debris to ensure more transparent and better regulated actions.

Every year, more than 4.8 million to 12.7 metric tons of plastic debris enter the sea, thus worsening the marine environment (Jambeck et al., 2015). The status of marine plastic debris, which is becoming increasingly widespread and dangerous, requires technological observation to determine the overall condition of the sea. One form of outer space technology that can be used for this purpose is satellites, which are regulated by international law, especially outer space law. Some international agreements related to the use of outer space technology such as satellites include the 1967 Treaty on Principle of Governing Activities of States in the Exploration and Use of Outer Space including the Moon and Other Celestial Bodies, the 1972 Convention International Liability for Damage Caused by Space Object, and the 1975 Convention on Registration of Objects Launched into Outer Space. Regulations through international law and national law will be important especially in various fields such as environmental law. The use of outer space technology is currently developing, especially in observing the ozone layer, climate change, biodiversity, management of hazardous and toxic materials and its waste, especially its movement, including marine plastic debris. (Andersen \& Sharma, 2002)

Good, accurate, and accountable data are needed to clearly regulate marine plastic debris. Data and information such as volume, distribution, type, position, impact, and new developments are needed for global management of marine plastic debris. Such data require accurate technology such as outer space technology, which includes satellites. Satellites can better evaluate and observe the presence of marine plastic debris to obtain information about the existence of various types of debris and their movement from the source toward the sea. Knowing how marine plastic debris circulates through marine currents and how seasons affect the movement of marine plastic debris is necessary.

This article examines marine plastic debris from a different perspective, namely, satellite technology. The use of satellite technology will enable the observation of the movement of marine plastic debris so that actions can be taken through mutual international agreement. International agreements with regard to the management of marine plastic debris can be drafted to limit, reduce, and even eliminate marine plastic debris. This study will development of the international law field. International law including international 
environmental law, international law of the sea and international outer space law has developed (Pramudianto, 2017). In the other hands, science is very important to development of international law. (For example, there is a gap for the long time, in the marine debris usually for the distribution with the show of one dimension. It needs change of paradigm and now, the show of three dimension among them satellite technology. This satellite technology will show new information and data for a good quality and become the basis data in international law.

\section{Methods}

This work used normative legal research (Soekanto, 1986) and the statutory and conceptual approaches (Marzuki, 2014). Primary data were obtained from legislation and international agreements, and secondary data were obtained from textbooks, journals, and other references. The data were then collected, identified, and analyzed. This research has done for three month and use location some libraries in Jakarta through the desk study.

The relevant data were sorted to determined which ones can be analyzed. Juridical analysis was conducted from the perspective of national regulations and international agreements. Normative analysis was conducted to identify norms that apply in national and international law, especially in outer space law and international environmental law. Conclusions and recommendations that can be useful for decision-makers were made.

\section{Results and Discussion}

\subsection{Sustainable Outer Space Law}

Air law has been developed since 1909 through discourse and publication (Syahmin, Utama, \& Idris, 2012). Outer space law began to develop since Sputnik was launched by the Soviet Union (now Russia) (Abdurassyid, 2008; Suherman, 2008; Syahmin et al., 2012). Further development came after the United Nations General Assembly issued Resolution XVIII on the Declaration of Legal Principles of Governing the Activities of States in the Exploration and Use of Outer Space dated December 13, 1963. The January 27, 1967 is an important date in the development of outer space law, with the approval of the Treaty on Principle Governing the Activities of States in the Exploration and Use of Outer Space including the Moon and Other Celestial Bodies. After the Russian satellite Cosmos fell in Canadian territory on March 29, 1972, the Convention on International Liability for Damage Caused by Space Objects was signed. The Convention on Registration of Objects Launched into Outer Space was signed three years later January 14, 1975 (United Nations, 2017).

Outer space law has developed rapidly since then, especially in the perspective of satellite regulations. The satellites launched today are not only owned by the state but also by the private sector. Some companies such as Space X (which produces observation satellites such as Falcon 1), Ad Astra Rocket Company, Blue Origin, Space Dev, Virgin Galactic, and CU Aerospace are private companies engaged in outer space.

Outer space law must develop in the current era of sustainable development. A sustainable outer space law must benefit future generations, especially about the marine environment to protect the common heritage of mankind (Wolfrum, 1983). A poor marine environment due to human exploitation or circulation of waste, especially plastic debris, from macroplastic, 
microplastic, to nanoplastic, will endanger future generations. Continuous changes in the paradigm of outer space law are needed.

\subsection{Types of Satellite Sea Observations and Regulations}

Some terms in outer space law must be known; for example, space objects are any objects, both man-made or natural, that are related to space. A spacecraft is defined as a man-made object related to space and its parts (Law Number 21 Year 2013). A popularly developed spacecraft is the satellite. Satellites have different types and functions. Some satellites can observe the development of chlorophyll production. Other satellites can observe winds at sea, the salinity, the current sea currents, and natural resources. Table 1 shows some satellites in use today.

Table 1. Sea observation satellites

\begin{tabular}{|c|c|c|c|}
\hline No. & Satellite Name & Function & Description \\
\hline 1. & COSMOS & $\begin{array}{l}\text { Obtains natural resource, navigation, and } \\
\text { marine data }\end{array}$ & RKA/Roscosmos \\
\hline 2. & $\begin{array}{l}\text { Joint Altimetry } \\
\text { Satellite } \\
\text { Oceanography } \\
\text { Network (JASON) }\end{array}$ & $\begin{array}{l}\text { Ocean bathymetry mapping. It was } \\
\text { upgraded through the TOPEX/Posideon } \\
\text { version to observe sea level rise. }\end{array}$ & $\begin{array}{l}\text { NASA (The } \\
\text { National } \\
\text { Aeronautics and } \\
\text { Space } \\
\text { Administration) }\end{array}$ \\
\hline 3. & Sea Star-Sea WiFS & $\begin{array}{l}\text { Determines the amount of chlorophyll } \\
\text { production in the sea }\end{array}$ & $\begin{array}{l}\text { NASA } \\
\text { Satellites are } \\
\text { widely used by } \\
\text { marine biology } \\
\text { researchers }\end{array}$ \\
\hline 4. & MOS & $\begin{array}{l}\begin{array}{l}\text { Observation of the earth and sea } \\
\text { environment }\end{array} \\
\end{array}$ & JAXA \\
\hline 5. & $\begin{array}{lr}\text { Soil } & \text { Moisture and } \\
\text { Ocean } & \text { Salinity } \\
(\text { SMOS }) & \end{array}$ & Observation of salinity & ESA \\
\hline 6. & QuickSCAT & $\begin{array}{l}\text { Measurement of the direction of sea } \\
\text { breezes for frozen seas }\end{array}$ & NASA \\
\hline 7. & SPOT & Land observation and oceanography & CNES \\
\hline 8. & Ice Sat & Coastline observation & NASA \\
\hline
\end{tabular}

(Sources: GISGeography, 2019)

Provisions regarding satellites, ranging from their design, manufacture, launch, movement, orbitals and function until they fail and/or fall to the earth, are regulated through national legislation and international treaties. The 1967 Treaty on Principle of Governing the Activities of States in the Exploration and Use of Outer Space including the Moon and Other Celestial Bodies regulates several important principles, such as activities that benefit the entire world, non-discrimination, equality, free access, free scientific research, international 
cooperation, and state responsibility. All principles should be adhered to by government agencies and non-governmental organizations. Satellites have a risk of falling back to Earth. In outer space, the length of time a satellite is not long and is like a vehicle (Bois, 2011). Problems with satellites are regulated by the 1972 Convention on International Liability for Damage Caused by Space Objects, which emphasizes several important terms, such as the launch, launch state, and space object. Space objects are components that include the vehicle being launched and its parts. A satellite that has been launched has several parts, including supporting parts and rockets; the latter is one of the most important parts and is used to deliver cargo to outer space and/or return the space vehicle, including its charge to the earth. The satellite launch process is shown below.

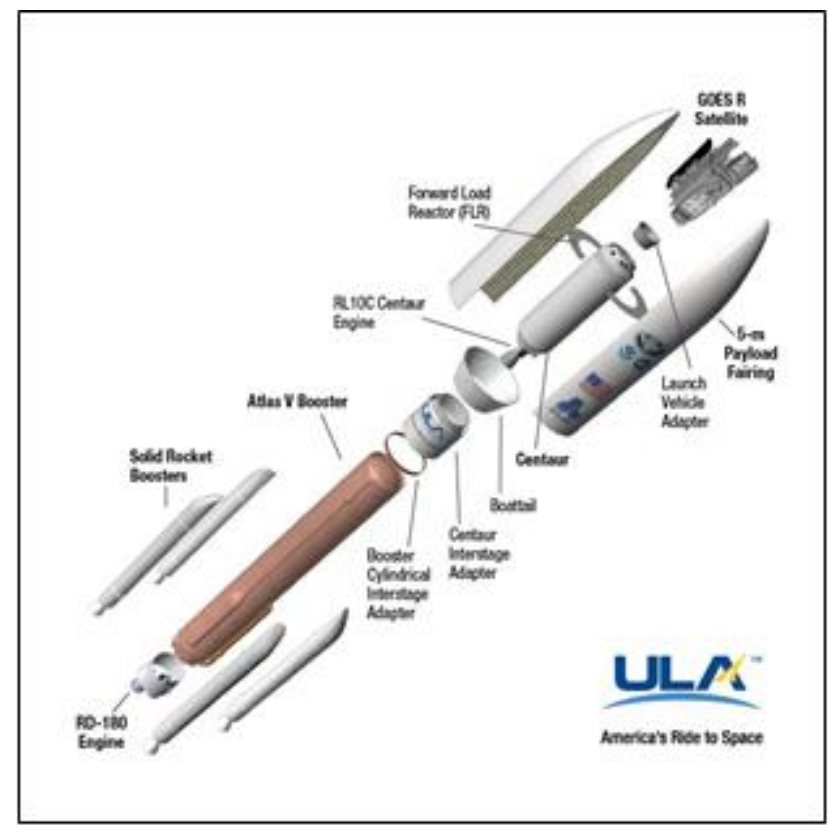

Figure 1. Device parts of a satellite launcher

(Source: Ray, 2016)

The absolute liability for a satellite remains with the launching country. Launching satellites requires accountability and registration. The 1975 Convention on Registration of Objects Launched into Outer Space states that the launching country must register every celestial body it launches with the UN Secretary General.

\subsection{Danger of Marine Plastic Debris and its Impact on Future Generations}

Garbage or debris in the marine is divided into seven categories (Shuker \& Cadman, 2018):
a. Plastic
b. Metal
c. Glass
d. Used wood
e. Paper and cardboard
f. Rubber
g. Clothing and textile 
Plastic debris consists of synthetic materials from polymers such as fishing nets, ropes, buoys, and other similar plastics used in fishing activities. Other materials containing plastics are used for daily activities, such as plastic bags, plastic bottles, plastic packaging, and plastic toys; cigarette-related materials, such as matches, cigarette butts, and cigarette wrappers; plastic resins, and various microplastic particles (Shuker \& Cadman, 2018). Plastic debris is currently circulating widely and can be found in all the world's oceans. Plastic waste exists in the form of macroplastic, microplastic, and nanoplastic (Avio, Gorbi, \& Regoli, 2017; Boucher \& Friot, 2017) Plastic debris can obscure the view of living things and block respiratory systems. They can also be swallowed by marine creatures that may mistake it for food, thus causing disease and even death (Thevenon, Carroll, \& Sousa, 2014).

In the 2002 New Delhi Declaration on Principles of International Law Relating to Sustainable Development, the International Law Association cited the protection of future generations as one of the important principles of sustainable development (Anonymous, 2002). The Sustainable Development Goals (SDGs) were agreed upon in 2015 by the United Nations General Assembly to replace the Millennium Development Goals. The SDGs that will be in effect until 2030 include marine protection in the 14th goal (SDG-14). This development is important because the Millennium Development Goals (2000-2015) did not consider marine protection. The SDGs aim to eliminate marine debris by 2030.

\subsection{Information, Communication, and Data as a Basis for Forming International Agreements}

Today, the world is undergoing important changes, including technology, that facilitate human life. Technology can be used to obtain information and data collection, as well as for transportation and communication. Information, data, and communication are essential in the development of national law and international law.

Remote sensing for monitoring marine plastic debris uses several models, such as the Surface Current from a Diagnostic model developed by NOAA, the Ocean Surface Current Analysis Real-time developed by the California Institute of Technology, the Surface Current Field model developed by the French oceanography analysis center Mercator, and the Center de Topographie des Ocean et de l'Hydrosphere model, which has since helped improve marine debris monitoring systems (Havens \& Albion, 2012).

The use of remote sensing models or geography information system (GIS) will make it easier to determine the presence of marine plastic debris. An example can be seen in the image below. 


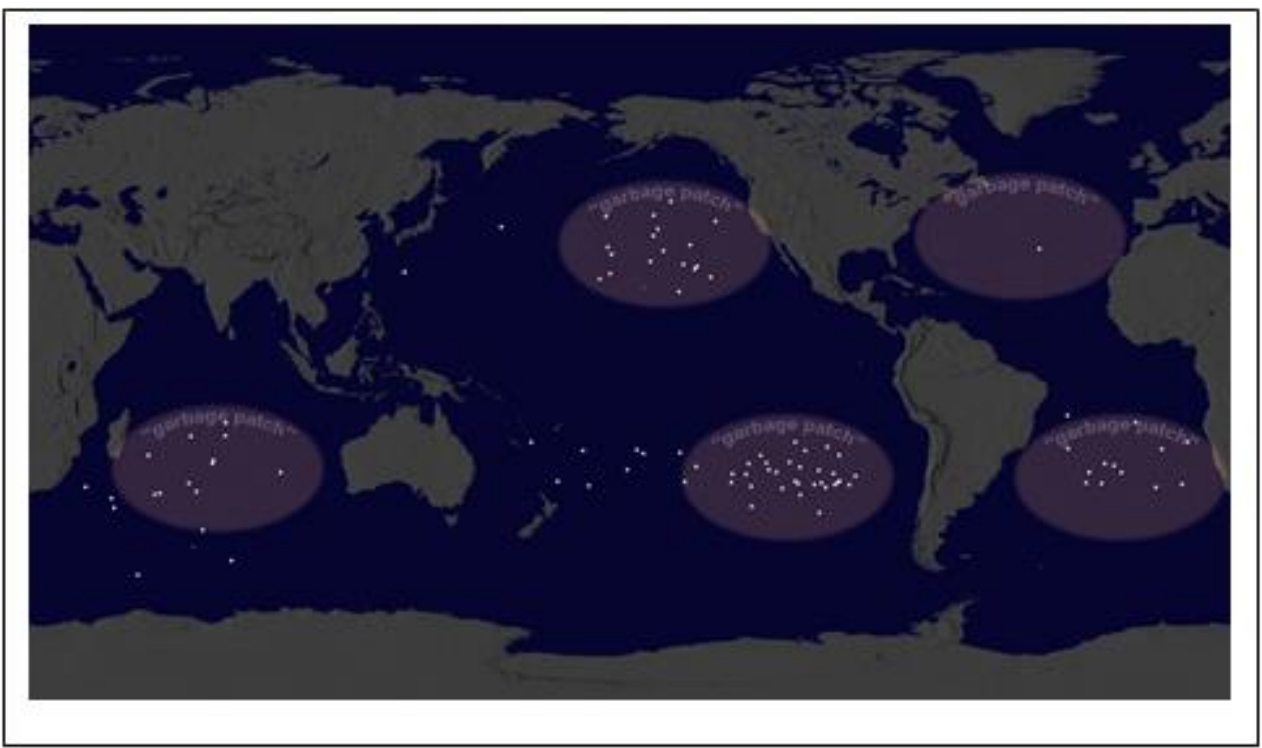

Figure 2. Spread of marine debris from satellite imagery

(Source: NASA)

A model has been created to simulate the movement of debris in the sea after the 2011 tsunami in Japan, as shown below.

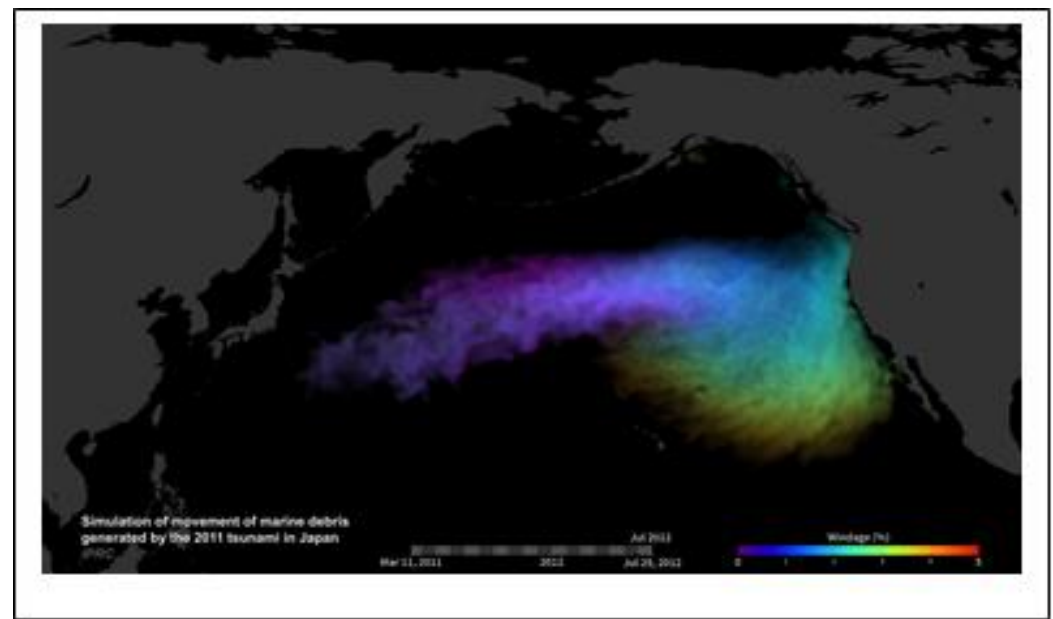

Figure 3. Simulation model of the movement of debris in the marine due to the tsunami

(Source: NASA)

\subsection{Indonesia's National Regulation on Space and Plastic Waste in the Sea}

In Indonesia, regulations regarding outer space are stipulated in Law Number 21 of 2013 Concerning Space Activities, which defines outer space to include all objects beyond the airspace. Space is defined as anything related to outer space and associated with the exploration and use of space. Other space-related activities mean exploration and utilization of space from Earth, the airspace, and in outer space.

The objectives of this law include providing a legal basis and certainty in the organization of space, ensuring the continuity of space management in the interests of the present and future generations, and realizing space administration, which is a supporting component of 
the defense and integrity of the Unitary Republic of Indonesia. Space activities include space science, remote sensing, mastery of space technology, launch, and commercial space activities. This law was implemented with due regard to national interests, security, and safety, the development of science and technology, human resources, benefits, effectiveness, and efficiency; the reliability of facilities and infrastructure of space; protection and management of the environment and the space environment; and the provisions of the legislation national invitations and international treaties to which Indonesia is a state party. Space research can be carried out using satellites and space stations, including observation facilities on Earth.

From another perspective, the law on waste is regulated through Law Number 18 of 2008 Concerning Waste Management. This law provides a general understanding of waste and specific waste. Waste is defined as the solid remnants of human daily activities and/or natural processes. Specific waste has types, concentration, and/or volume that need to be managed specifically. Waste management is defined as systematic, holistic, and sustainable activities, including waste reduction and handling.

From this law, legal instruments were derived, including government, presidential, ministerial, and regional regulations. Presidential Regulation No. 83 of 2018 concerning Handling of Marine Debris is among these regulations. This regulation provides an appendix to the National Action Plan (NAP) for handling marine debris, with the goal of $70 \%$ reduction in marine debris by 2025.

Table 2 lists some regulations related to plastic waste.

Table 2. Policies and regulations related to wastes, plastic waste, or marine debris

\begin{tabular}{|c|c|c|c|}
\hline No. & Name & Rule Important & Provision Remarks \\
\hline 1. & 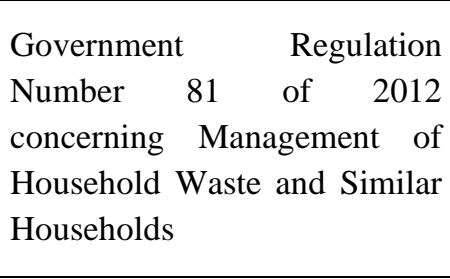 & $\begin{array}{l}\text { This government regulation covers the } \\
\text { regulation of waste management policies } \\
\text { and strategies; organizing waste } \\
\text { management; compensation; technology } \\
\text { development and application; information } \\
\text { systems; community role; and coaching. }\end{array}$ & $\begin{array}{l}\text { Guidance needs to } \\
\text { provide further } \\
\text { regulation regarding the } \\
\text { implementation. }\end{array}$ \\
\hline 2. & $\begin{array}{l}\text { Presidential Regulation No. } 97 \\
\text { of } 2017 \text { concerning Policies } \\
\text { and Strategies for Managing } \\
\text { Household Trash and Similar } \\
\text { Household Trash. }\end{array}$ & $\begin{array}{l}\text { Policy and National Strategy or Kebijakan } \\
\text { dan Strategi Nasional (Jakstranas) wastes } \\
\text { includes policy direction on reducing and } \\
\text { handling household waste and household } \\
\text { type waste; reduction strategies, programs } \\
\text { and targets and Handling of Household } \\
\text { Trash and Trash A Type of Household } \\
\text { Trash }\end{array}$ & $\begin{array}{l}\text { A connection to marine } \\
\text { plastic debris must be } \\
\text { made within the } \\
\text { framework of Jaktranas. }\end{array}$ \\
\hline 3. & \begin{tabular}{lrr} 
Presidential & \multicolumn{2}{c}{ Regulation } \\
Number 83 & Year & 2018 \\
concerning & Handling & of \\
Marine Debris & &
\end{tabular} & $\begin{array}{l}\text { Marine debris is defined as rubbish } \\
\text { originating from land, water bodies, and } \\
\text { coastline that flows into the sea or rubbish } \\
\text { originating from activities at sea. } \\
\text { Marine plastic debris is waste that } \\
\text { contains polymer compounds. }\end{array}$ & $\begin{array}{l}\text { The clear use of satellite } \\
\text { technology and } \\
\text { institutions need to be } \\
\text { added, namely, the } \\
\text { National Institute of } \\
\text { Aeronautics and Space } \\
\text { or Lembaga } \\
\text { Penerbangan dan } \\
\text { Antariksa Nasional }\end{array}$ \\
\hline
\end{tabular}




\begin{tabular}{|c|c|c|c|}
\hline No. & Name & Rule Important & Provision Remarks \\
\hline & & & $\begin{array}{lr}\text { LAPAN) } & \text { and } \\
\text { Geospatial } & \text { Information } \\
\text { Agency } & \text { or } \quad \text { Badan } \\
\text { Informasi } & \text { Geospasial } \\
(\mathrm{BIG}) & \\
\end{array}$ \\
\hline 4. & $\begin{array}{l}\text { Regulation of the Minister of } \\
\text { Environment and Forestry } \\
\text { Number P.10/MENLHK/ } \\
\text { SETJEN/PLB.0/4/2018 } \\
\text { concerning Guidelines for the } \\
\text { Preparation of Regional Policy } \\
\text { and Strategy for Household } \\
\text { Waste Management and } \\
\text { Household-like Waste. }\end{array}$ & $\begin{array}{l}\text { Regulates policies for waste management } \\
\text { in the area, including strategies and } \\
\text { programs. }\end{array}$ & $\begin{array}{l}\text { Government in regions, } \\
\text { especially those have } \\
\text { coastal areas, small } \\
\text { islands and the sea, must } \\
\text { have a policy to reduce } \\
\text { marine debris. }\end{array}$ \\
\hline 5. & $\begin{array}{l}\text { Circular of the Ministry of } \\
\text { Environment and Forestry } \\
\text { Number: } \\
\text { SE.8/PSLB3/PS/PLB.0/5/2016 } \\
\text { concerning Reduction of } \\
\text { Plastic Waste through the } \\
\text { Application of Non-Free } \\
\text { Disposable Shopping Bags }\end{array}$ & $\begin{array}{l}\text { The purpose of reducing waste generation } \\
\text { at sources of waste producers and using } \\
\text { plastic shopping bags through non-free } \\
\text { disposable plastic shopping bags }\end{array}$ & $\begin{array}{l}\text { The form of regulations } \\
\text { needs to be elevated to a } \\
\text { higher level such as } \\
\text { ministerial regulation. }\end{array}$ \\
\hline 6. & $\begin{array}{l}\text { State Civil Service Agency } \\
\text { Circular Letter Number K26- } \\
\text { 30/V 30-10/99 dated February } \\
\text { 21, 2019, concerning Appeal } \\
\text { to Not Use Plastic Drinking } \\
\text { Water Packaging. }\end{array}$ & $\begin{array}{l}\text { Appeals to avoid the use of plastic } \\
\text { packaging for drinking water and plastic } \\
\text { bags for domestic waste }\end{array}$ & $\begin{array}{l}\text { A good example and } \\
\text { needs to be improved. }\end{array}$ \\
\hline 7. & $\begin{array}{l}\text { Bogor Mayor Regulation } \\
\text { Number } 61 \text { Year } 2018 \\
\text { concerning Reduction of Use } \\
\text { of Plastic Bags }\end{array}$ & $\begin{array}{l}\text { Plastic bags are bags made from or } \\
\text { containing plastic, latex or polyethylene, } \\
\text { thermoplastic synthetic polymeric } \\
\text { materials, or other similar materials, with } \\
\text { or without controls, which are used as } \\
\text { media to lift or transport goods. }\end{array}$ & $\begin{array}{l}\text { This regulation must be } \\
\text { implemented } \\
\text { continuously. }\end{array}$ \\
\hline 8. & $\begin{array}{l}\text { Padang Mayor Regulation } \\
\text { Number } 36 \text { Year } 2018 \\
\text { concerning Control of Use of } \\
\text { Plastic Shopping Bags } \\
\text { Protecting from pollution and/ } \\
\text { or environmental damage from } \\
\text { the use of plastic shopping } \\
\text { bags }\end{array}$ & $\begin{array}{l}\text { Goals to reduce the use of plastic } \\
\text { shopping bags should be fulfilled for the } \\
\text { present and future generations. }\end{array}$ & $\begin{array}{l}\text { This regulation uses the } \\
\text { principle of sustainable } \\
\text { development, with focus } \\
\text { on future generations. }\end{array}$ \\
\hline 9. & $\begin{array}{l}\text { Denpasar Mayor Regulation } \\
\text { Number } 36 \text { Year } 2018 \\
\text { concerning Reduction of Use } \\
\text { of Plastic Bags }\end{array}$ & $\begin{array}{l}\text { The reduction in the use of plastic bags is } \\
\text { aimed at controlling the occurrence of } \\
\text { pollution and/or environmental damage } \\
\text { caused by the use of plastic bags and } \\
\text { guaranteeing the survival of living things } \\
\text { and the preservation of ecosystems. }\end{array}$ & $\begin{array}{l}\text { Ecosystem sustainability } \\
\text { is an important concern, } \\
\text { and respect for the } \\
\text { marine ecosystem is } \\
\text { highlighted. }\end{array}$ \\
\hline 10. & $\begin{array}{lccr}\text { Bekasi } & \text { Mayor } & \text { Regulation } \\
\text { Number } & 21 & \text { of } & 2016 \\
\end{array}$ & $\begin{array}{l}\text { Regulations regarding the reduction of } \\
\text { plastic bags are carried out based on the }\end{array}$ & $\begin{array}{l}\text { This regulation includes } \\
\text { the principle of }\end{array}$ \\
\hline
\end{tabular}




\begin{tabular}{|c|c|c|c|}
\hline No. & Name & Rule Important & Provision Remarks \\
\hline & $\begin{array}{l}\text { concerning Reduction of Use } \\
\text { of Plastic Bags in Bekasi City }\end{array}$ & $\begin{array}{l}\text { principles of responsibility; sustainability } \\
\text { and sustainability; harmony and balance; } \\
\text { cohesiveness; benefits; awareness; safety; } \\
\text { fairness; and participatory nature. }\end{array}$ & sustainable development. \\
\hline 11. & $\begin{array}{l}\begin{array}{l}\text { Surabaya Mayor Circular } \\
\text { Letter } \\
\text { Number: }\end{array} \\
\text { 660./13197/436.7.12/2018 } \\
\text { concerning Appeal to Reduce } \\
\text { Plastic Waste }\end{array}$ & $\begin{array}{l}\text { Four tasks must be completed, including } \\
\text { avoiding the use of styrofoam and plastic } \\
\text { materials for packaging. }\end{array}$ & $\begin{array}{l}\text { This regulation needs to } \\
\text { be elevated from being a } \\
\text { mere mayor regulation. }\end{array}$ \\
\hline
\end{tabular}

Laws were made to clarify rules that did not yet exist and were based on the needs and commitment to higher regulations. Creating such laws, especially in the international Law of the Sea or international environmental law, requires good data. Obtaining good data on marine plastic debris requires technology, particularly outer space technology. The outer space law provides guidance on technology, such as the use of satellites as a research tool. Marine debris in Indonesia needs to be reduced in accordance with the NAP for reducing marine debris by $70 \%$ by 2025 . Satellite technology is needed to detect marine plastic debris in Indonesian waters. Legal and institutional instruments must support the relationship between outer space technology, namely satellites, and efforts to reduce debris in Indonesian waters. However, no relationship seems to exist between NAP and outer satellite technology for the availability of information, data, and communication on the presence of marine plastic debris. Such relationship is important for readiness and implementation to evaluation through adequate information and data to reduce marine plastic debris.

Therefore, the NAP should be improved to include satellite technology and relevant institutions, such as National Institute of Aeronautics and Space (LAPAN) and the Geospatial Information Agency (BIG), in handling marine debris.

One impact of technological development, including space technology, is the need for regulation through legal instruments, especially international law, which includes branches such as the outer space law, the international Law of the Sea, and international environmental law. The current outer space law needs to be changed with the new concept and its paradigm. In an era of sustainable development where future generations are an important focus, the outer space law must also be able to look forward. An outer space law that looks to the future and is based on sustainable development can be called sustainable outer space law.

The outer space law also regulates outer space technology such as the use of satellites. Satellites can be used in all fields, but they need to be regulated to avoid disputes or conflicts. Satellites that can observe marine plastic debris are currently needed, including their movements, which can be identified and analyzed so that the management of marine plastic debris can be pursued through international law, especially the international Law of the Sea and international environmental law.

An agreement between countries is needed and can be set out in a more adequate international agreement for handling marine debris, especially marine plastic debris. International agreements can be done bilaterally, regionally, or multilaterally. Handling of marine plastic debris in the sea adjacent or facing each other can be settled through a bilateral agreement, through regional international agreements for countries in a certain region, or 
through a global international agreement. For example, ASEAN is addressing marine plastic debris through a joint commitment entitled the Bangkok Declaration on Combating Marine Debris in ASEAN Region on June 22, 2019.

A good international agreement requires information, data, and communication that can be acquired through technology such as satellite technology. With the use of satellite technology, any technical provisions and legal norms that can be met and agreed upon will affect the formation of international agreements. Satellite technology will support better efforts in the process of drafting and forming international agreements especially from a technical and scientific point of view. The development of satellite technology and the use of other celestial technologies will undoubtedly influence the development of outer space law.

A healthy marine condition is desirable. This idea is in accordance with the SDGs, specifically target 14 (SDG-14). However, marine conditions are currently increasingly worsening. Pollution in the sea such as the presence of marine plastic debris is increasing every year. Plastic that becomes wastes, garbage, or rubbish in the sea is crushed into macroplastic, microplastic, and even nanoplastic. This situation is unfavorable to living creatures that depend on the sea. The food chain affected by the presence of marine plastic debris will ultimately endanger humans today or the current generation. If not resolved, latent hazards of marine plastic debris will occur in the future, thereby also endangering future generations.

We need clean and sustainable seas, which can be achieved by reducing the volume and distribution of marine plastic debris. Concrete action has been needed since 2015 for the 14 SDGs to be achieved by 2030. However, it is not too late to implement various efforts to reduce the volume of marine debris. Developing technology, utilizing economic value, providing adequate funding, increasing the ability of human resources, and developing effective institutions are all possible ways. Policies and strict legislation at the national level with the support of all countries through international hard and soft laws will facilitate the achievement of the SDGs target.

The development of satellite technology, which can monitor the presence of marine plastic debris, and a more detailed technology for observing various types of debris in the sea and its distribution and movement will increase efforts to control and deal with marine debris. An adequate management and monitoring system will further support the reduction of marine plastic debris. Outer space technology coupled with the ability to use the GIS model and its application is expected to clearly observe the presence, movement, and position of marine plastic debris spread. Seas are highly dynamic and cannot be seen from only one dimension of space; they must also be seen from four dimensions, including the bottom of the sea, thus requiring more advanced technology, including satellite technology.

With adequate technology, information, data, and communication will be more useful and can be utilized in an effort to try and reduce the existence of marine plastic debris. Through legal instruments such as national legislation based on technology development systems, the target of reducing marine plastic debris is expected to be achieved. Likewise, international agreements that can adapt to developments and technological capabilities will encourage the reduction of marine plastic debris globally.

Finally, Indonesia as an archipelagic state that has a vast coastline and cannot be adequately observed through marine and land vision. Space and air perspectives are needed 
for a wider view on the existence of marine plastic debris throughout the territory of the Unitary Republic of Indonesia. Satellite technology will help the NAP in handling marine debris by knowing the position, movement, and spread of marine plastic debris. However, the seas are dynamic; hence, any observed marine plastic debris may not be in the same location as when it was found. Advanced technologies such as real-time satellites that specifically look at the movement of marine plastic debris are needed.

Further questions that might not have been resolved by this work will provide some important directions for subsequent research, including the following:

a. How can sustainable outer space law, which expands traditional outer space law, be developed?

b. Can the current satellite technology see the position of marine plastic debris in detail? Is a follow-up device needed for information and data obtained from satellites?

c. Are there more effective ways to remove marine plastic debris, from macroplastic, microplastic, to nanoplastic forms?

d. Can the 14 SDGs be achieved by 2030 through policies, regulations, or international agreements?

e. Is international law, especially the international Law of the Sea and international environmental law, sufficient to handle and deal with marine plastic debris? Is more detailed international cooperation needed?

f. The existing national legislation such as in Indonesia aims to reduce marine waste by $70 \%$ by 2025 , a process that needs to be assisted by outer space technology such as satellites. Does the national legal instrument automatically adjust to the technology, especially satellite technology, and how prepared are the relevant institutions to handle it?

Discussions from this study are expected to benefit all interested parties in handling plastic waste at sea at the national, regional, and global levels.

\section{Conclusion}

The existence of marine plastic debris must be addressed by all countries, including Indonesia. Marine plastic debris is becoming increasingly dangerous for all living things that depend on the sea. The sea provides a future for humanity. Therefore, the SDGs include marine protection. Threats to the marine environment will threaten future generations. International cooperation is needed to overcome this problem, and this can be facilitated through information, data, and communication technology.

One such technology is space technology, such as satellites. Space technology that can view the whole sea or ocean and marine plastic debris, especially its movements, can provide important information for drafting and formulating policies and laws, especially national legislation and international agreements.

This research has answered the mean question is the handle of marine debris with the use satellite is important and it is changing the new paradigm in the field of international outer space law traditional become international sustainable development outer space law. Its need the new research deeply about international sustainable development outer space law.

The recommendations of this research is Indonesia's National Action Plan (NAP) on Marine Debris already addresses the problem of marine debris, but it is still incomplete due to 
the lack of utilization of satellite technology. Satellite technology input is needed, as well as handling institutions such as LAPAN, BIG, LIPI, and BPPT to help reach the 70\% reduction target for marine debris by 2025.

This paper provides new insights on viewing marine plastic debris from the perspective of international law, especially sustainable outer space law, the international Law of the Sea, and international environmental law. Despite the limited knowledge and time, this paper is expected to encourage further in-depth research.

\section{Author Contributions}

Andreas Pramudianto as author are fully handling the whole article

\section{References}

Abdurasyid, P. (2008). National Space Law: The Application of Its Urgency (Hukum Angkasa Nasional: Penerapan Urginsinya). Jakarta: Rajawali Press.

Andersen, S. O., \& Sharma, K. M. (2002). Protecting the Ozone Layer: The United Nations History. New York: Routledge.

Anonymous. (2002). ILA New Delhi Declaration on Principles of International Law Relating to Sustainable Development. International Environmental Agreement: Politics, Law and Economics, 2, 211-216. https://doi.org/10.1023/A:1020905309876

Avio, C. G., Gorbi, S., \& Regoli, F. (2017). Platics and Microplatic in the Ocean: From Emerging Pollutant to Emerged Threat. Marine Environmental Research, 128, 2-11. https://doi.org/10.1016/j.marenvres.2016.05.012

Bois, R. de. (2011). Space Waste. Germany: Franz Weber Foundation.

Boucher, J., \& Friot, D. (2017). Primary Microplastics in the Ocean. A Global Evaluation $\begin{array}{llll}\text { Sources. } & \text { Swiss: } & \text { RUCN. } & \text { from }\end{array}$ https://portals.iucn.org/library/sites/library/files/documents/2017-002.pdf

Burkhoder, E. F. (2017). The 3-D Global Spatial Data Model: Principles and Application. New York: CRC Press.

Derraik, J. G. B. (2002). The Pollution of the Marine Environment by Plastic Debris: A Review. Marine Pollution Bulletin, 44, 842-852. https://doi.org/10.1016/S0025$326 \mathrm{X}(02) 00220-5$

GISGeography. (2019). 50 Satellites You Need To Know: Earth Satellite List. Retrieved from https://gisgeography.com/earth-satellite-list/\#chapter5

Greenberg, N., \& Moore, C. C. (2011). Talks Trash, EAIl'I ISLAND J., Aug.10, 2011.

Harse, G. A. (2011). Plastic, The great pacific garbage patch, and international misfires at a cure. Journal Environmental Law, 29, 331-363. Retrieved from https://escholarship.org/uc/item/4pp84809

Havens, Z. W, \& Albion, M. I. (2018). The Remote Sensing of Marine Plastics. Departement of Environmental Science of University Virginia. Retrieved from https://libraetd.lib.virginia.edu/downloads/5h73pw50c?filename=1

Jambeck, J. R., Geyer, R., Wilcox, C., Siegler, T. R., Perryman, M., Andrady, A., Narayan, R., \& Law, K. L. (2015). Plastic waste inputs from land into the ocean. Science, $347(6223)$, $768-771$.

Retrieved from 
https://www.iswa.org/fileadmin/user_upload/Calendar_2011_03_AMERICANA/Science2015-Jambeck-768-71__2_.pdf

Marzuki, P. M. (2014). Research on Law (Penelitian Hukum). Jakarta: Prenadamedia Group. Moore, C. J., Moore, S. L., Leecaster, M. K., \& Weisberg, S. B. (2001). A Comparison Plastic and Plankton in the North Pacific Central Gyre. Marine Pollution Bulletin, 42(12), 1297-1300. https://doi.org/10.1016/S0025-326X(01)00114-X

NASA. Scientific Visualization Studio. Retrieved from https://svs.gsfc.nasa.gov/

Pramudianto, A. (2017). International Environmental Law (Hukum Lingkungan Internasional). Depok: Penerbit CV Rajawali.

Ray, J. (2016). Preview: Weather satellite to touch the lives of every American ready to launch. Retrieved from https://spaceflightnow.com/2016/11/16/weather-satellite-that-willtouch-the-lives-of-every-american-ready-to-launch/

Shuker, I. G., \& Cadman, C. A. (2018). Indonesia - Marine debris hotspot rapid assessment: synthesis report (English). Marine Debris Hotspot Rapid Assessment (Synthesis Report). Washington: World Bank Group. Retrieved from http://documents.worldbank.org/curated/en/983771527663689822/Indonesia-Marinedebris-hotspot-rapid-assessment-synthesis-report

Soekanto, S. (1986). Introduction to Research on Law (Pengantar Penelitian Hukum). Jakarta: UI Press.

Suherman, E. (2008). Airspace and Aerospace Territories (Wilayah Udara dan Wilayah Dirgantara). Bandung: Penerbit Alumni.

Syahmin, A. K., Utama, M., \& Idris, A. (2012). Air and Space Law (Hukum Udara dan Luar Angkasa). Palembang: Penerbit UNSRI Press.

Thevenon, F., Carroll, C., \& Sousa, J. (2014). Plastic Debris in the Ocean: The Characterization of Marine Plastics and their Environmental Impacts, Situation Analysis Report. Gland, Switzerland: IUCN. Retrieved from https://portals.iucn.org/library/sites/library/files/documents/2014-067.pdf

United Nations. (2017). International Space Law: United Nations Instrument. Vienna: United Nations Officer for Outer Space. Retrieved from https://www.unoosa.org/oosa/oosadoc/data/documents/2017/stspace/stspace61rev.2_0.ht $\mathrm{ml}$

Vegter, A. C., Beck, C., Borrero, J., Burton, H., Campbell, M. L., Costa, M. F., ... Hamann, M. (2014). Global research priorities to mitigate plastic pollution impacts on marine wildlife. Endangered Species Research, 25, 225-247. http://doi.org/10.3354/esr00623

Wolfrum, R. (1983). The Principle of Common Heritage of Mankind. Max-Planck-Institut für ausländisches öffentliches Recht und Völkerrecht. Retrieved from https://www.zaoerv.de/43_1983/43_1983_2_a_312_337.pdf 